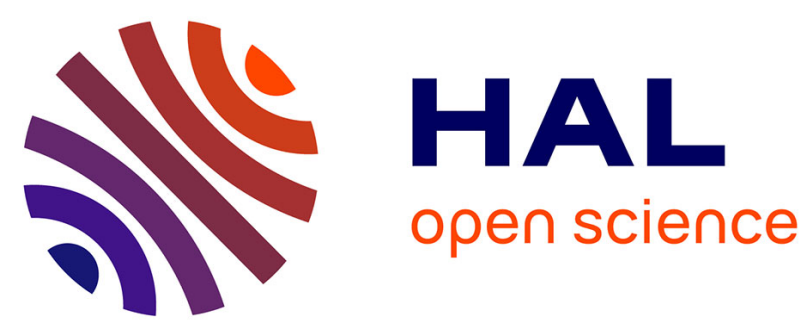

\title{
PREVALENCE OF DIFFERENT HPV TYPES AND ESTIMATION OF PROGNOSTIC RISK FACTORS BASED ON THE LINEAR ARRAY HPV GENOTYPING TEST
}

Eleni Papachristou, Vana Sypsa, Dimitrios Paraskevis, Athanasios Gkekas, Ekaterini Politi, Electra Nicolaidou, Ioannis Anifantis, Mina Psichogiou, Artemis Tsitsika, Maria Hadjivassiliou, et al.

\section{- To cite this version:}

Eleni Papachristou, Vana Sypsa, Dimitrios Paraskevis, Athanasios Gkekas, Ekaterini Politi, et al.. PREVALENCE OF DIFFERENT HPV TYPES AND ESTIMATION OF PROGNOSTIC RISK FACTORS BASED ON THE LINEAR ARRAY HPV GENOTYPING TEST. Journal of Medical Virology, 2009, 81 (12), pp.2059. 10.1002/jmv.21639 . hal-00531829

\author{
HAL Id: hal-00531829 \\ https://hal.science/hal-00531829
}

Submitted on 4 Nov 2010

HAL is a multi-disciplinary open access archive for the deposit and dissemination of scientific research documents, whether they are published or not. The documents may come from teaching and research institutions in France or abroad, or from public or private research centers.
L'archive ouverte pluridisciplinaire HAL, est destinée au dépôt et à la diffusion de documents scientifiques de niveau recherche, publiés ou non, émanant des établissements d'enseignement et de recherche français ou étrangers, des laboratoires publics ou privés. 
Journal of Medical Virology

WILEY

\section{PREVALENCE OF DIFFERENT HPV TYPES AND ESTIMATION OF PROGNOSTIC RISK FACTORS BASED ON THE LINEAR ARRAY HPV GENOTYPING TEST}

\begin{tabular}{|r|l|}
\hline Journal: & Journal of Medical Virology \\
\hline Manuscript ID: & JMV-09-1258.R2 \\
\hline Diley - Manuscript type: & Research Article \\
\hline Author: & 23-Jul-2009 \\
\hline Complete List of Authors: & $\begin{array}{l}\text { PAPACHRISTOU, ELENI; UNIVERSITY OF ATHENS, DEPARTMENT OF } \\
\text { HYGIENE EPIDEMIOLOGY AND MEDICAL STATISTICS } \\
\text { SYPSA, VANA } \\
\text { PARASKEVIS, DIMITRIOS } \\
\text { GKEKAS, ATHANASIOS } \\
\text { POLITI, EKATERINI } \\
\text { NICOLAIDOU, ELECTRA } \\
\text { ANIFANTIS, IOANNIS } \\
\text { PSICHOGIOU, MINA } \\
\text { TSITSIKA, ARTEMIS } \\
\text { HADJIVASSILIOU, MARIA } \\
\text { PETRIKKOS, GEORGIOS } \\
\text { KATSAMBAS, ANDREAS } \\
\text { CREATSAS, GEORGIOS } \\
\text { Hatzakis, Angelos; Athens University Medical School, Hygiene and } \\
\text { Epidemiology }\end{array}$ \\
\hline Keywords: & HPV genotyping, HPV prevalence, PCR \\
\hline
\end{tabular}

\section{$\diamond$ ScholaroNE" \\ Manuscript Central}




\section{PREVALENCE OF DIFFERENT HPV TYPES AND ESTIMATION OF PROGNOSTIC RISK FACTORS BASED ON THE LINEAR ARRAY HPV GENOTYPING TEST}

Eleni Papachristou ${ }^{1}$, Vana Sypsa ${ }^{1}$, Dimitrios Paraskevis ${ }^{1}$, Athanasios Gkekas ${ }^{2}$, Ekaterini Politi ${ }^{2}$, Electra Nicolaidou ${ }^{3}$, Ioannis Anifantis ${ }^{4}$, Mina Psichogiou ${ }^{4}$, Artemis Tsitsika ${ }^{5}$, Maria Hadjivassiliou ${ }^{3}$, Georgios Petrikkos ${ }^{4}$, Andreas Katsambas ${ }^{3}$, Georgios Creatsas ${ }^{2}$, Angelos Hatzakis ${ }^{1}$.

${ }^{1}$ Department of Hygiene and Epidemiology and Medical Statistics, University of Athens School of Medicine, ${ }^{2} 2^{\text {nd }}$ Department of Obstetrics and Gynecology, Aretaieion Hospital, University of Athens, School of Medicine , ${ }^{3}$ Sexually Transmitted Infections Unit, $1^{\text {st }}$ Department of Dermatology and Venereology, University of Athens, School of Medicine, A.Syggros Hospital, ${ }^{4}$ Infectious Diseases Research Laboratory "G.K Daikos" University of Athens, School of Medicine, Laiko General Hospital Athens, ${ }^{5}$ Adolescent Health Unit, $2^{\text {nd }}$ Department of Pediatrics, University of Athens School of Medicine, "P.and A. Kyriakou" Children's Hospital, Greece

Correspondence to: Angelos Hatzakis

Department of Hygiene Epidemiology and Medical Statistics, Medical School, University of Athens

Mikras Asias 75, GR-11527,

Athens, Greece

E-mail:ahatzak@med.uoa.gr 


\begin{abstract}
The aim of the study was to evaluate the prevalence and risk factors of HPV in a gynecological population attending outpatient clinics using two new molecular tests. The Amplicor HPV test and the Linear Array HPV Genotyping test (LA) were used for the detection of HPV DNA in 320 women. Multiple logistic regression was used to identify independent prognostic factors of HPV positivity.

The agreement between the two methods in terms of their qualitative results was 89.3\% (kappa: 0.63). Based on the LA results, the overall prevalence of HPV DNA was $49.1 \%$ (95\% CI: $43.5 \%, 54.7 \%)$. The prevalence of high-risk HPV types was 30.3\%. The predominant types were HPV-6 (24.8\%) and HPV-16 (20.4\%). Among women with normal cytology, the prevalence of HPV was much higher in those presenting other findings, such as inflammation, than those without other abnormal findings $(49.5 \%$ vs. $31.5 \%)$. On the basis of multivariate analysis, the risk of HPV infection was higher among women with multiple sexual partners ( $>3$ vs. 1 : $\mathrm{OR}=3.1$, 95\% CI: $(1.5,7.2)$ ), Pap smear findings (low/high-grade lesions vs. negative: $\mathrm{OR}=2.8$, 95\% CI: $(1.2,6.5)$ ), the presence of warts (yes vs. no: $\mathrm{OR}=3.0,95 \% \mathrm{CI}:(1.5,6.3)$ ) and no history of child birth (no vs. yes: $\mathrm{OR}=2.6,95 \% \mathrm{CI}$ : $(1.0,6.7)$ ). Younger age was an additional risk factor for HPV infection with carcinogenic genotypes (OR for 1 -year increase $=0.93,95 \% \mathrm{CI}:(0.89,0.98))$.
\end{abstract}

Key words: HPV prevalence, HPV genotyping, PCR 


\section{Introduction}

Cervical cancer is the second most frequent female cancer worldwide resulting in about 270,000 deaths annually [Ferlay et al., 2005; Munoz., 2000; Parkin et al., 1990].The association of HPV infection with the development of cervical cancer and its precursor lesions has been well established [Munoz., 2000; Bosch et al., 2002; Clifford et al., 2003; Wallboomers et al., 1999; Wallin et al., 1999]. Recent studies have shown that HPV DNA can be found in $99.7 \%$ of all cervical cancers, with HPV types 16,18,45,31 being the most frequent [Wallboomers et al., 1999; Koutsky et al., 2002]. HPVs are non-enveloped double-stranded DNA viruses which belong to the Papillomaviridae family, which consist of more than 100 different HPV genotypes, 40 of which infect the genital tract [Chan et al., 1995; de Villiers et al., 2004; zur Hausen., 1991] and cause mainly transient infections [Evader et al., 1995; Rosenfeld et al., 1992; Hinchilfe et al., 1995]. Based on the etiological role in the progression to cervical cancer, 15 HPV genotypes have been classified as high risk, 3 genotypes $(26,53,66)$ have been classified as probable high risk, 12 genotypes (such as 6,11 which are detected frequently in benign lesions such as condylomata accuminata) have been classified as low risk and 3 genotypes $(34,57,83)$ are classified as of undetermined risk [Munoz et al., 2003).

Genotyping is, among others, important for epidemiological studies for the evaluation of HPV infections worldwide [van Hamont et al., 2006; Ferenczy et al., 2002; Meier et al., 2006]. The aim of the study was to evaluate the prevalence and risk factors of HPV among women who visited the outpatient clinics of four hospitals of Athens, for gynecological examination and Pap-test, using a linear assay HPV DNA test assessing the 37 most common anogenital HPV genotypes. 


\begin{abstract}
METHODS
Patients

320 cervical scrapes were collected from November, 2005 until March, 2008 from 320 apparently healthy women 16-71 years of age who attended the gynecological or the infectious diseases outpatient clinic of Aretaieion, A.Syggros, "P\&A Kyriakou" Childrens' and Laiko hospitals of Athens, Greece. Many of the women had genital warts, abnormal Pap smears or other vaginal infections. The study was approved by the Institutional Review Board of Athens University Medical School and an informed consent from the patients was obtained.
\end{abstract}

\title{
Methods
}

The samples were collected in PreservCyt solution (Cytyc Corporation ${ }^{\circledR}$, Marlborough, USA) with a Cervex-brush ${ }^{\circledR}$ (Rovers Medical Devices B.V., The Netherlands) and stored at $2-8^{0} \mathrm{C}$ according to the manufacturer's instructions.The cervical scrapes were examined by using two assays available commercially: the Amplicor ${ }^{\circledR}$ HPV test, and the Linear Array HPV Genotyping test (LA) (both from Roche Molecular Systems, Inc., Branchburg, NJ USA).The Amplicor HPV test is a qualitative in vitro test for the detection of 13 high risk HPV genotypes $(16,18,31,33,35,39,45,51,52,56,58,59,68)$ while the LA is a qualitative in vitro test for the detection of 37 anogenital HPV genotypes(including high risk HPVs detected by the Amplicor HPV test) in cervical cells. Both tests are based on four major processes: specimen preparation, PCR amplification of the target DNA, hybridization of the amplified products to oligonucleotide probes and detection of the 
probe-bound amplified products by colorimetric determination [Gravitt et al., 2000; Davies et al., 2001].

HPV DNA was extracted from the samples using the Amplilute Liquid Media, (Roche Molecular Systems, Inc., Branchburg, NJ USA) according to the manufacturer's instructions. The Amplicor HPV test uses a pool of biotinylated primers which amplify an approximately $165 \mathrm{bp}$ sequence within the polymorphic L1 region of the genome of 13 high risk HPV genotypes.

The LA Genotyping test uses a pool of biotinylated primers designed to amplify an approximately $450 \mathrm{bp}$ sequence within the polymorphic L1 region of the genome of 37 HPV genotypes. An additional 268 primer pair which targets the human $\beta$-globin gene is included in both assays to provide a control for cell adequacy, extraction and amplification. After completion of the PCR, amplified DNA is denatured and is added either into wells of a microwell plate which contain either HPV or $\beta$-globin probes or on strips which are covered with HPV and $\beta$-globin oligonucleotide probes.

Data analysis and epidemiological associations were based on Linear Array HPV Genotyping test. The prevalence of HPV was estimated as the proportion of women with HPV DNA positive test and the $95 \%$ confidence interval $(95 \% \mathrm{CI})$ was also calculated. The chi-squared test or the t-test was used to examine the presence of association between HPV DNA status and the characteristics of the patient. Multiple logistic regression was used to identify independent prognostic factors for HPV positivity. 


\section{RESULTS}

\section{Study participants}

The characteristics of the women participating in the study are shown in Table1. Their age ranged from 16-71 years with a mean (SD) of 28.4 (8.7) years. Approximately one third of the women (31\%) had warts and 50.5\% reported more than three lifetime sexual partners. The age of first sexual contact ranged from 13-34 years with a mean (SD) of 18.0 (2.6) years. Only $17.3 \%$ of the enrolled women had at least one child and $15.1 \%$ reported at least one abortion (Table 1$)$.

\section{Comparison of the Amplicor HPV test and the Linear Assay}

The agreement between the two methods in terms of their qualitative results was 89.3\% (kappa: 0.63). In one sample it was not possible to obtain a result by Amplicor HPV test. All Amplicor HPV negative samples ,except one, were either negative (75.2\%) with the LA test or low risk genotypes (24.3\%)were found (Table 5).

\section{Prevalence of $\mathrm{HPV}$}

Taking into account all 37 genotypes, 157 women (49.1\%) were found to be positive for any HPV type (95\% Confidence Interval (CI): (43.6\%, 54.6\%)). Approximately one third of the infections (36.9\%) involved only one HPV type while the prevalence of infections with two and three or more types was $33.8 \%$ and $29.3 \%$, respectively. The prevalence $(95 \% \mathrm{CI})$ of high-risk HPV infections was $30.3 \%(25.3 \%, 35.7 \%)$.

The genotype which was identified most frequently among infected women was HPV6 (24.8\%) followed by HPV16 (20.4\%), HPV42 (17.8\%), HPV51 (14.7\%), HPVCP6108 and HPV31 (12.7\%), HPV52 and HPV62 (12.1\%), HPV66 (10.2\%), HPV53 (8.9\%), HPV84 (7.6\%), HPV59 and HPV18 (7\%), HPV56 and HPV61 $(6.4 \%)$. (Table 2) 


\section{Prognostic factors of HPV infection: Univariate analysis}

The prevalence of HPV in women $<25,25-29,30-34,35-39$ and over 40 years of age was $52.1 \%, 55.4 \%, 46.8 \%, 41.4 \%$, and $29 \%$ respectively (p=0.104) (Fig.1). The prevalence of HPV increased with increasing number of sexual partners. More specifically, among women with one, two, three and more than three lifetime partners, the prevalence of HPV was $27.4 \%, 36.2 \%, 51.1 \%$ and $61.1 \%$, respectively $(\mathrm{p}<0.001)$ (Table 3). According to the Pap test result, the prevalence of HPV was $100 \%$ for the high-grade smears (3/3), $62.9 \%$ for low-grade (44/70), 33.3\% for the Atypical Squamous Cells of Undetermined Significance (ASCUS) smears (10/30) and 31.5\% for the negative smears without any other findings $(17 / 54)(\mathrm{p}=0.001)$. In negative smears with other findings such as inflammation, trachilitis, fungi and condylomata the prevalence of HPV was $49.5 \%(51 / 103)(\mathrm{p}=0.001)($ Table 3$)$.

The prevalence of HPV in women who had external genital warts was higher compared to those without warts $(62 \%$ and $42.7 \%$ respectively, $\mathrm{p}=0.001)$. Among women who had given at least one birth, the prevalence of HPV was $29.1 \%(16 / 55)$ whereas in those with no births the corresponding rate was 53.6\% (141/263), $(\mathrm{p}=0.001)$. HPV was detected at similar rates in smokers and non-smokers $(52.8 \%$ and $46.7 \%$ respectively, $\mathrm{p}=0.282$ ) (Table 3 ).

Considering only the high risk HPV genotypes, the detection rates in women $<25$, $25-29,30-34,35-39$ and over 40 years of age were $34.7 \%, 32.6 \%, 31.9 \%, 20.7 \%$ and $12.9 \%$ respectively (Table 3). The prevalence of high risk types in women with one, two, three and more than three lifetime partners was $14.5 \%, 19.2 \%, 37.8 \%$, and $37.6 \%$ respectively $(\mathrm{p}=0.002)$. The detection rates of one or more high risk genotypes in high grade, low grade, Atypical Squamous Cells of Undetermined Significance 
(ASCUS), and negative Pap-smears without any other finding were 100\% (3/3), 47.1 $\%(33 / 70), 13.3 \%(4 / 30)$ and $14.8 \%(8 / 54)$ respectively. In negative smears with some other findings such as inflammation, trachilitis, fungi and condylomata the detection rate was $30 \%(31 / 103)(\mathrm{p}<0.001)$. In women who had external genital warts, high risk types were detected in $33 \%(33 / 100)$ of women $(\mathrm{p}=0.409)$. High risk types were detected in $18.2 \%(10 / 55)$ of those who had given at least one birth whereas in those without a history of births the detection rate was 33\% (87/263), $(\mathrm{p}=0.029)$. Among smokers, high risk types were detected in 34.2\% (55/161) of women and in non-smokers the respective rate was $27 \%(41 / 152)$ (Table 3$)$.

\section{Prognostic factors of HPV infection: Multivariate analysis}

In multiple logistic regression, detection of any HPV was associated with presence of genital warts $(\mathrm{OR}=3.0,95 \% \mathrm{CI}$ : 1.5-6.3, $\mathrm{p}=0.003)$, multiple sexual partners $(>3$ partners vs. 1 : $\mathrm{OR}=3.2,95 \% \mathrm{CI}: 1.5-7.0 \mathrm{p}=0.004)$ and presence of low/high-grade lesions ( $\mathrm{OR}=2.8,95 \% \mathrm{CI}:$ 1.2-6.5, $\mathrm{p}=0.014)$ (Table 4). There was a marginal association between the absence of births and risk for HPV, i.e. women reporting no births were at higher risk of being HPV positive relative to those with children $(\mathrm{OR}=2.56,95 \% \mathrm{CI}: 0.99-6.66, \mathrm{p}=0.054)$ (Table 4).

Multiple logistic regression was also used to identify prognostic factors of HPV infection with high risk types. Older women had a reduced risk of being positive for a high risk HPV type $(\mathrm{OR}=0.9$, 95\%CI: 0.9-0.98, $\mathrm{p}=0.008)$, while multiple sexual partners ( 3 partners vs. 1$)$ increased the risk by four times (OR=4.0, 95\%CI: 1.4-12.0, $\mathrm{p}=0.012$ ). In women with low/high-grade lesions the risk of infection with a high risk type was increased compared to women with a normal Pap test $(\mathrm{OR}=5.6,95 \% \mathrm{CI}$ : 2.1-14.5, $\mathrm{p}<0.001)$ (Table 4). 


\section{DISCUSSION}

This is the first study on HPV prevalence conducted in Greece which is based on an up-to-date laboratory method. The main question was to estimate both the prevalence and the associated risk factors of HPV in a gynecological population attending outpatient clinics using two nucleic acid amplification-based tests.

Our sample allowed the estimation of the prevalence with a precision of $5.5 \%$. To date, data on this topic in the Greek population are very limited. Patients'participation in the study was rather slow and a prolonged period for sample collection would be needed to attain the sample size goal which was 500 patients. The population studied does not represent the general population as it includes women who were attending the clinic for medical advice and treatment for vaginal infections. Of course there were women who underwent cytology testing as a routine examination. It should be noted that in Greece there is no organised screening programme so many women choose to have a Pap test while others had never been tested cytologically until symptoms developed.

The prevalence of the different HPV types was based on the Linear Array test. In addition all the samples were also examined by the Amplicor HPV test in order to evaluate the performance of the two tests. Both tests are based on nucleic acid amplification. The use of the LA results allowed an estimation of the prevalence of any HPV and of high-risk types as well as the associated risk factors.

The agreement between the two methods in terms of their qualitative results was $89.3 \%$ (kappa: 0.63 ). In one sample it was not possible to obtain a result by the Amplicor HPV test (Table 5). All Amplicor HPV negative samples ,except one, were either negative $(75.2 \%)$ by the LA test or identified low risk genotypes (24.3\%). This 
indicates that the Amplicor test could be used as a screening test for high risk HPV types followed by the LA test which provides information not only on the involved genotype but also on the persistence with the same genotype, which is a major risk factor for progression to cervical cancer.

In the study by Mo et al (2008) the Amplicor test was compared with the Hybrid Capture II and since both assays did not differ in terms of sensitivity and specificity they could be used for the detection of high risk HPV DNA with similar efficacy in specimens collected in the PreservCyt solution. On the other hand, Sandri et al (2006) found that the Amplicor test provided a larger number of positive results in women with normal smears and this difference may be due to the fact that the Hybrid Capture II is characterized by a signal amplification step.

In this study, the prevalence of the HPV types among women attending outpatient gynecological clinics was found to be $49.1 \%$. When only women with negative Pap test and the absence of other findings were considered, the corresponding prevalence was $31.5 \%$. From the limited epidemiological data in Greece, Kroupis et al [2007] mentioned that the prevalence of HPV in an almost similar study group was $60 \%$ with types 16, 53 and 6 being the most frequent. In women with normal cytology the respective rate was $23.6 \%$. Panotopoulou et al [2007] found a prevalence of $53.6 \%$ of HPV, with types 11 and 18 being the most frequent. It should be noted that the above study group differed from the present study as it involved a $10 \%$ of women with Squamous Cell Carcinoma. Nevertheless, in the women with normal cytology of that study the prevalence of HPV was $26.4 \%$, whereas in another study conducted by Agorastos et al [1995] for asymptomatic women with normal cytology in Northern Greece, the respective prevalence was $36.3 \%$. The higher detection rates of HPV observed in younger women, when compared to older women, falls with increasing 
age and this finding is in agreement with many other published studies [Jacobs et al., 2000; De Roda et al., 1995; Cuzick et al., 1999]. This can be a result of either reduced sexual activity and less high risk behavior factors such as unprotected sex or acquired immunity to HPV from past exposure [Burk et al., 1996a;]. Furthermore, older women were also found to have a reduced risk of infection with a carcinogenic HPV type.

It is known that there is a positive association between the number of sexual partners and the infection with HPV [Burk et al., 1996b; Tarkowski et al., 2004]. In the present study, multiparity increased the risk of harboring HPV by 3-4 times when compared with the women who declared a single partner.

The presence of carcinogenic HPV types is greater in abnormal smears and many studies have demonstrated that the prevalence of HPV increases in parallel with the severity of cervical lesions [Jacobs et al., 2000; Grce et al., 2001; Evans et al., 2006]. In terms of finding of HPV in normal smears, the results of the current study suggest that in women with negative smears but with inflammation, trachilitis, fungi and genital warts, the prevalence of high risk HPV types was greater than in those with negative smears without any other findings. In previous studies [Singh et al., 1995; Parashari et al., 1995] negative smears with inflammation were suspicious for HPV infection, whereas in the study of Arora et al., [2005] a 10\% of women who had a negative Pap smear with inflammation had high-risk types HPV16 and 18.

The risk of detecting HPV in the cervix was three times higher when patients had genital warts. Other studies show that women with genital warts may be at an increased risk for harboring high risk HPV types [Mosciki et al., 2001] and have a Cervical Intraepithelial Neoplasia risk up to six times greater [Ward et al., 1994] than 
women in the general population [Sellors et al., 2000] since external genital warts may be a marker of a relative deficiency in immune response [Shlay et al., 1998].

The absence of births in a woman doubles approximately the risk of infection with HPV. Several studies [Veress et al., 1996; Fife et al., 1996; Fife et al., 1999; Nobbenhuis et al., 2002] show that during pregnancy the rate of HPV detection increases due to hormonal changes or immunological factors which lead to activation of HPV. This activation may trigger the immune system to respond and thus clear the virus.

Smoking did not seem to influence the prevalence of HPV in this and other studies [Tarkowski et al., 2004; Deacon et al., 2000]. Other studies show that smoking is not only associated with an increased prevalence of HPV, but also that the prevalence of HPV increases with smoking [Vaccarella et al., 2008;] whereas Hildesheim et al [1994] and Ho et al [1998] found that smoking was a potentially protective factor against persistent HPV infection.

The availability of HPV vaccines may change the future epidemiology of HPV. It would be of interest to monitor this natural experiment by periodical studies on the prevalence of HPV types in cervical cells.

ACKNOWLEDGEMENTS The authors would like to thank Roche Molecular Systems for providing the test kits and the Hellenic Scientific Society for the Study of AIDS and Sexually Transmitted Diseases for financial support. 


\section{REFERENCES}

Agorastos T, Bontis J, Lambropoulos AF, Constantinidis TC, Nasioutziki M, Tagou

C, Katsouyiannopoulos V.1995.Epidemiology of human papillomavirus infection in Greek asymptomatic women. Eur J Cancer Prev: 4:159-67

Arora R, Kumar A, Prusty K, Kailash U, Batra S, Das BC.2005. Prevalence of highrisk human papillomavirus (HR-HPV) types 16 and 18 in healthy women with cytologically negative Pap smear. Eur J of Obstetr and Reproduc Biol: 121:104-109 Bosch FX, Lorinez A, Munoz N, Meijer CJ, Shah KV.2002The causal relation between human papillomavirus and cervical cancer. J Clin Pathol: 55:244-265

Burk RD, Kelly P, Feldman J, Vermund SH, DeHovitz JA, Landesman SH.1996.Declining prevalence of cervicographical human papillomavirus infection with age is independent of other risk factors. Sex Transm Dis: 23:333-41

Burk RD, Ho GY, Beardsley L, Lempa M, Peters M, Bierman R.1996.Sexual behavior and partner characteristics are the predominant risk factors for genital human papillomavirus infection in young women. J Infect Dis : 174:679-89

Chan SY, Delius H, Halpern AL, Bernard HU.1995 Analysis of genomic sequences of 95 papillomavirus types: uniting typing, phylogeny and taxonomy. J Virol: 69: 30743083

Clifford GM., Smith JS, Plummer M, Munoz N, Franceschi S. 2003Human papillomavirus types in invasive cervical cancer worldwide: a meta-analysis. $\mathrm{Br} \mathbf{J}$ Cancer: 88:63-73

Cuzick J, Beverley E, Ho L, Terry G, Sapper H, Mielzynska I, Lorincz A, Chan WK, Krausz T, Soutter P.1999.HPV testing in primary screening of older women. Br J Cancer: $81: 554-8$ 
Davies P, Kornegay J, Iftner T. Current methods of testing for human papillomavirus. 2001. Best Practice and Research Clinical Obstetrics and Gynaecology: 15:677-700

De Roda Husman AM, Walboomers JM, Hopman E, Bleker OP, Helmerhorst TH, Rozendaal L, Voorhorst FJ, Meijer CJ.1995. HPV prevalence in cytomorphologically normal cervical scrapes of pregnant women as determined by PCR: the age-related pattern. J Med Virol: 46:97-192

de Villiers EM, Fauquet C, Broker TR, Bernard HU, zur Hausen H.2004.Classification of papillomaviruses. Virology: 324:17-27

Deacon JM, Evans CD, Yule R, Desai M, Taylor C, Peto J.2000.Sexual behavior and smoking as determinants of cervical HPV infection and CIN3 among those infected:a case-control study nested within the Manchester cohort. Br J Cancer: 83: 1565-1572

Evader M, Edlund K, Gustafsson A, Jonsson M, Karlsson R, Rylander E, Wadell G. 1995.Human papillomavirus infection is transient in young women: a populationbased cohort study. J Infect Dis : 171 :1026-30

Evans FM, Adamson CS.-C, Papillo JL, St John TL, Leiman G, Cooper K.2006 Distribution of human papillomavirus types in Thin-Prep Papanicolaou Tests according to the Bethesda 2001 terminology and correlations with patient age and biopsy outcomes. Cancer: 106:1054-64

Ferenczy A, Franco EL.2002. Persistent human papillomavirus infection and cervical neoplasia. Lancet Oncol: 3: 11-16

Ferlay J, Bray F, Pisani P, Parkin DM. 2005. GLOBOCAN 2002: cancer incidence, mortality and prevalence worldwide, version 2.0. IARC Cancer Base No.5 IARC Press, Lyon, France [online] http://www-depdb.iarc.fr/globocan/GLOBOframe.htm. 
Fife KH, Katz BP, Roush J, Handy VD, Brown DR, Hansell R.1996.Cancerassociated human papillomavirus types are selectively increased in the cervix of women in the first trimester of pregnancy. Am J Obstet Gynecol :174:1487-1493

Fife KH, Katz BP, Brizendine EJ, Brown DR.1999.Cervical human papillomavirus deoxyribonucleic acid persists throughout pregnancy and decreases in the postpartum period. Am J Obstet Gynecol :180:1110-1114

Gravitt PE, Peyton CL, Alessi TQ, Wheeler CM, Coutlee F, Hildesheim A, Schiffman MH, Scott DR, Apple RJ.2000.Improved amplification of genital human papillomaviruses. J Clin Microbiol : 38 :357-361

Grce M, Husnjak K, Magdic'L, Zlacki M, Lucac J, Fistonic'I, Sikanic'-Dugic' N, Pavelic' K.2001.Evaluation of genital human papillomavirus infections by polymerase chain reaction among Croatian women. Anticancer Res: 21:579-84

Hildesheim A, Schiffman MH, Gravitt PE, Glass AG, Greer CE, Zhang T, Scott DR, Rush BB, Lawler P, Sherman ME et al.1994.Persistence of type specific human papillomavirus infection among cytologically normal women. J Infect Dis : 169:23540

Hinchliffe SA, van Velzen D, Korporaal H, Kolk PL, Boon ME.1995Transience of cervical HPV infection in sexually active, young women with normal cervicovaginal cytology. Br J Cancer: 72:943-5

Ho YFG, Bierman R, Beardsley L, Chang JC, Burk DR.1998. Natural history of cervicovaginal papillomavirus infection in young women. N Engl J Med: 338:423-8

Jacobs MV, Walboomers JM, Snijders PJ, Voorhorst FJ, Verheijen RH, FransenDaalmeijer N, Meijer CJ.2000.Distribution of 37 mucosotropic HPV types in women with cytologically normal cervical smears: the age -related patterns for high-risk and low-risk types. Int J Cancer: 87:221-227 
Koutsky LA, Ault KA, Wheeler CM, Brown DR, Barr E, Alvarez FB, Chiacchierini LM, Jansen KU. 2002. A controlled trial of a human papillomavirus type 16 vaccine. N Engl J Med: 347:1645-51

Kroupis C, Thomopoulou G, Papathomas TG, Vourlidis N, Lazaris AC.2007.

Population-based study of human papillomavirus infection and cervical neoplasia in Athens, Greece Epidemiol Infect : 135:943-950

Meijer CJ, Snijders PJ, Castle PE. 2006. Clinical utility of HPV genotyping. Gynecol Oncol: 103: 12-17

Mo LZ, Monnier-Benoit S, Kantelip B, Petitjean, Riethmuller D, Pretet JL, Mougin C.2008. Comparison of AMPLICOR and Hybrid Capture II assays for high risk HPV detection in normal and abnormal liquid-based cytology: Use of INNO-LiPA Genotyping assay to screen the discordant results. J Clin Virol:41:104-110

Moscicki AB, Hills N, Shiboski S, Powell K, Jay N, Hanson E, Miller S, Clayton L, Farhat S, Broering J, Darragh T, Palefsky J.2001.Risks for incident human papillomavirus infection and low grade squamous intraepithelial lesion development in young females. JAMA: 285:2995-3002

Munoz, N., 2000.Human papillomavirus and cancer: the epidemiological evidence J Clin Virol 2000; 19:1-5

Munoz N, Bosch FX, de Sanjose S, Herrero R, Castellague X, Shah KV, Snijders PJ, Meijer CJ.2003 Epidemiologic classification of human papillomavirus types associated with cervical cancer. N Engl J Med: 348:518-527

Nobbenhuis MAE, Helmerhorst TJM, van den Brule AJC, Rozendaal L, Bezemer PD, Voorhorst FJ, Meijer CJLM.2002 High-risk human papillomavirus clearance in pregnant women: trends for lower clearance during pregnancy with a catch-up postpartum. Br J Cancer: 87:75-80 
Panotopoulou E, Tserkazoglou A, Kouvousi M, Tsiaousi I, Chatzieleftheriou G, Daskalopoulou D, Magiakos D. 2007. Prevalence of human papillomavirus types 6, 11,16,18,31 and 33 in a cohort of Greek women. J Med Virol :79:1898-1905 Parashari A, Singh V, Gupta MM, Satyanarayana L, Chattopadhya D, Sodhani P, Sehgal A.1995. Significance of inflammatory cervical smears. APMIS. 103:273-278 Parkin DM, Pisani P, Ferlay J. 1999 Estimates of the worldwide incidence of 25 major cancers in 1990. Int. J. Cancer: 80:827-841

Rosenfeld WD, Rose E, Vermund SH, Schreiber K, Burk RD.1992.Follow-up evaluation of cervicographical human papillomavirus infection in adolescents. $\mathrm{J}$ Pediatr: 121:307-311

Sandri TM, Lentati P, Benini E, Dell'Orto P, Zorzino L, Carozzi MF, Maisonneuve P, Passerini R, Salvatici M, Casadio C, Boveri S, Sideri M.2006. Comparison of the Digene HC2 Assay and the Roche AMPLICOR Human Papillomavirus (HPV) Test for Detection of High-Risk HPV Genotypes in Cervical Samples. J Clin Microb: $44: 2141-2146$

Sellors JW, Mahony JB, Kaczorowski J, Lytwyn A, Bangura H, Chang S, Lorincz A, Dalby DM, Janjusevic V, Keller JL.2000. Prevalence and predictors of human papillomavirus infection in women in Ontario, Canada. CMAJ: 163:503-508. Available:www.cma.ca/cmaj/vol-163/issue-5/0503.htm

Shlay JC, McGill WL, Masloboeva HA, Douglas JM Jr.1998.Pap smear screening in an urban STD clinic. Sex Transm Dis: 25:468-75

Singh V, Gupta MM, Satyanarayana L, Parashari A, Sehgal A, Chattopadhya D, Sodhani P.1995. Association between reproductive tract infections and cervical inflammatory epithelial changes. Sex Transm Dis: 22:25-30 
Tarkowski TA, Koumans EH, Sawyer M, Pierce A, Black CM, Papp JR, Markowitz L, Unger ER.2004 .Epidemiology of human papillomavirus and abnormal cytologic test results in an urban adolescent population. J Infect Dis : 189: 46-50

Vaccarella S, Hieu NT, Ferreccio C, et al IARC HPV Prevalence Surveys (IHPS) Study Group. Smoking and human papillomavirus infection: pooled analysis of the International Agency for Research on Cancer HPV Prevalence Surveys. Int J Epidemiol 2008; 37:536-546

Van Hamont D, van Ham Maaike APC, Bakkers Judith MJE, Massuger Leon FAG, Melches Willem JG.2006 Evaluation of the SPF 10 -INNOLiPA Human Papillomavirus (HPV) Genotyping Test and the Roche Linear Array HPV Genotyping Test. J Clin Microbiol: 44:3122-3129.

Veress G, Csiky-Meszaros T, Konya J, Czegledy J, Gergely L.1996. Follow-up of human papillomavirus (HPV) DNA and local anti- HPV antibodies in cytologically normal pregnant women. Med Microbiol Immunol.1996: 185:139-44

Wallboomers JM, Jacobs MV, Manos MM, Bosch FX, Kummer JA, Shah KV.1999.Human papillomavirus is a necessary cause of invasive cervical cancer worldwide. J Pathol: 189: 12-19

Wallin KL, Wiklund F, Angstrom T, Bergman F, Stendahl U, Wadell G, Hallmans G, Dillner J.1999.Type-specific persistence of human papillomavirus DNA before the development of invasive cervical cancer.

N Engl J Med.:341: 1633-1638

Ward KA, Lowry BE, Houston JR, Maw RD.1994.Cervical epithelial abnormalities in females with and without genital warts. Int J STD AIDS: 5:380-1

Zur Hausen H.1991 Human papillomaviruses in the pathogenesis of anogenital cancer. Virology: 184:9-13 
Table 1: Characteristics of 320 healthy women with cervical scrapes.

\begin{tabular}{|c|c|}
\hline AGE (years) & \\
\hline$<25$ & $121(37.8 \%)$ \\
\hline $25-29$ & $92(28.8 \%)$ \\
\hline $30-34$ & $47(14.7 \%)$ \\
\hline $35-39$ & $29(9.1 \%)$ \\
\hline $40+$ & $31(9.7 \%)$ \\
\hline \multicolumn{2}{|l|}{$\begin{array}{l}\text { NUMBER OF LIFETIME } \\
\text { SEXUAL PARTNERS, n(\%) }\end{array}$} \\
\hline 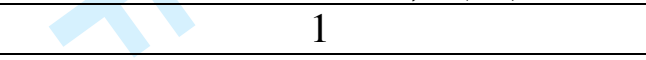 & $62(19.9 \%)$ \\
\hline 2 & $47(15.1 \%)$ \\
\hline 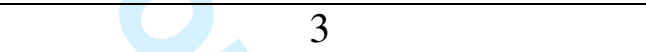 & $45(14.5 \%)$ \\
\hline$>3$ & $157(50.5 \%)$ \\
\hline \multicolumn{2}{|l|}{$\begin{array}{l}\text { NUMBER OF DELIVERIES, } \\
n(\%)\end{array}$} \\
\hline 0 & $263(82.7 \%)$ \\
\hline 1 & $25(7.9 \%)$ \\
\hline 2 & $23(7.2 \%)$ \\
\hline $3-2$ & $7(2.2 \%)$ \\
\hline \multicolumn{2}{|l|}{$\begin{array}{l}\text { NUMBER OF MISCARRIAGES, } \\
\text { n }(\%)\end{array}$} \\
\hline 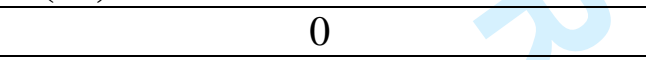 & $304(95.6 \%)$ \\
\hline$\sqrt{2-2}$ & $9(2.8 \%)$ \\
\hline 2 & $2(0.6 \%)$ \\
\hline 3 & $3(0.9 \%)$ \\
\hline \multicolumn{2}{|l|}{$\begin{array}{l}\text { NUMBER OF ABORTIONS, } \\
\text { n }(\%)\end{array}$} \\
\hline 0 & $270(84.9 \%)$ \\
\hline 1 & $32(10.1 \%)$ \\
\hline 2 & $10(3.1 \%)$ \\
\hline 3 & $4(1.3 \%)$ \\
\hline 4 & $2(0.6 \%)$ \\
\hline \multicolumn{2}{|l|}{ PRESENCE OF WARTS, n (\%) } \\
\hline $\mathrm{NO}$ & $218(69.0 \%)$ \\
\hline YES & $100(31.0 \%)$ \\
\hline \multicolumn{2}{|l|}{ SMOKING, n (\%) } \\
\hline NO & $152(49.0 \%)$ \\
\hline YES & $161(51.0 \%)$ \\
\hline \multicolumn{2}{|l|}{$\begin{array}{l}\text { AGE OF FIRST SEXUAL } \\
\text { CONTACT }\end{array}$} \\
\hline Mean (SD) & $18(2.6)$ \\
\hline Range & $13-34$ \\
\hline
\end{tabular}


Table 2. Prevalence of HPV types in single and any infections

\begin{tabular}{|c|c|c|}
\hline HPV type & $\begin{array}{l}\text { Single infections } \\
(\mathrm{N}=58)\end{array}$ & $\begin{array}{c}\text { Any infection } \\
(N=157)\end{array}$ \\
\hline 6 & $15.5 \%$ & $24.8 \%$ \\
\hline 11 & $0.0 \%$ & $0.6 \%$ \\
\hline 16 & $15.5 \%$ & $20.4 \%$ \\
\hline 18 & $1.7 \%$ & $7.0 \%$ \\
\hline 26 & $0.0 \%$ & $0.0 \%$ \\
\hline 31 & $12.1 \%$ & $12.7 \%$ \\
\hline 33 & $0.0 \%$ & $2.6 \%$ \\
\hline 35 & $0.0 \%$ & $1.9 \%$ \\
\hline 39 & $0.0 \%$ & $2.6 \%$ \\
\hline 40 & $0.0 \%$ & $0.0 \%$ \\
\hline 2 & $5.2 \%$ & $17.8 \%$ \\
\hline ( & $0.0 \%$ & $0.6 \%$ \\
\hline 51 & $5.2 \%$ & $14.7 \%$ \\
\hline 52 & $3.5 \%$ & $12.1 \%$ \\
\hline 53 & $1.7 \%$ & $8.9 \%$ \\
\hline 54 & $1.7 \%$ & $3.2 \%$ \\
\hline 55 & $3.5 \%$ & $3.2 \%$ \\
\hline 56 & $1.7 \%$ & $6.4 \%$ \\
\hline 58 & $0.0 \%$ & $4.5 \%$ \\
\hline 59 & $5.2 \%$ & $7.0 \%$ \\
\hline 61 & $1.7 \%$ & $6.4 \%$ \\
\hline 62 & $3.5 \%$ & $12.1 \%$ \\
\hline 64 & $0.0 \%$ & $1.3 \%$ \\
\hline 66 & $5.2 \%$ & $10.2 \%$ \\
\hline 67 & $3.5 \%$ & $5.7 \%$ \\
\hline 68 & $1.7 \%$ & $3.8 \%$ \\
\hline 69 & $0.0 \%$ & $0.6 \%$ \\
\hline 70 & $1.7 \%$ & $0.6 \%$ \\
\hline 71 & $0.0 \%$ & $0.6 \%$ \\
\hline 72 & $0.0 \%$ & $0.6 \%$ \\
\hline 73 & $0.0 \%$ & $4.5 \%$ \\
\hline 82 & $0.0 \%$ & $0.0 \%$ \\
\hline 81 & $0.0 \%$ & $3.8 \%$ \\
\hline 83 & $0.0 \%$ & $3.2 \%$ \\
\hline 84 & $5.2 \%$ & $7.6 \%$ \\
\hline IS39 & $0.0 \%$ & $0.6 \%$ \\
\hline CP6108 & $5.2 \%$ & $12.7 \%$ \\
\hline
\end{tabular}


Table 3: Univariate associations between potential risk factors and HPV or high risk prevalence of HPV.

\begin{tabular}{|c|c|c|c|c|c|}
\hline \multirow{2}{*}{$\begin{array}{l}\text { PROGNOSTIC } \\
\text { FACTORS }\end{array}$} & \multirow{2}{*}{$\mathbf{N}$} & \multicolumn{2}{|c|}{ HPV (+) (any type) } & \multicolumn{2}{|c|}{ HPV (+) (high risk types) } \\
\hline & & $\mathbf{n}(\%)$ & $\mathbf{P}$ & n $(\%)$ & $\mathbf{P}$ \\
\hline \multicolumn{6}{|l|}{ AGE } \\
\hline$<25$ & 121 & $63(52.1)$ & \multirow{5}{*}{0.104} & $42(34.7)$ & \multirow{5}{*}{0.253} \\
\hline $25-29$ & 92 & $51(55.4)$ & & $30(32.6)$ & \\
\hline $30-34$ & 47 & $22(46.8)$ & & $15(31.9)$ & \\
\hline $35-39$ & 29 & $11(41.4)$ & & $6(20.7)$ & \\
\hline $40+$ & 31 & $9(29.0)$ & & $4(12.9)$ & \\
\hline \multicolumn{6}{|l|}{$\begin{array}{l}\text { No. OF } \\
\text { LIFETIME } \\
\text { SEXUAL } \\
\text { PARTNERS }\end{array}$} \\
\hline 1 & 62 & $17(27.4)$ & \multirow{4}{*}{$<0.001$} & $9(14.5)$ & \multirow{4}{*}{0.002} \\
\hline 2 & 47 & $17(36.2)$ & & $9(19.1)$ & \\
\hline 3 & 45 & $23(51.1)$ & & $17(37.8)$ & \\
\hline$>3$ & 157 & $96(61.1)$ & & $59(37.6)$ & \\
\hline \multicolumn{6}{|l|}{ PAP-TEST } \\
\hline Negative & 54 & $17(31.5)$ & \multirow{5}{*}{0.001} & $8(14.8)$ & \multirow{5}{*}{$<0.001$} \\
\hline Negative+other & 103 & $51(49.5)$ & & $31(30.1)$ & \\
\hline ASCUS $^{*}$ & 30 & $10(33.3)$ & & $4(13.3)$ & \\
\hline LGSIL $^{\dagger}$ & 70 & $44(62.9)$ & & $33(47.1)$ & \\
\hline HGSIL $^{+}$ & 3 & $3(100.0)$ & & $3(100.0)$ & \\
\hline \multicolumn{6}{|l|}{ WARTS } \\
\hline $\mathrm{NO}$ & 218 & $93(42.7)$ & \multirow[b]{2}{*}{0.001} & $62(28.4)$ & \multirow[b]{2}{*}{0.409} \\
\hline YES & 100 & $62(62.0)$ & & $33(33.0)$ & \\
\hline \multicolumn{6}{|l|}{ DELIVERIES } \\
\hline $\mathrm{NO}$ & 263 & $141(53.6)$ & \multirow[b]{2}{*}{0.001} & $87(33.1)$ & \multirow[b]{2}{*}{0.029} \\
\hline YES & 55 & $16(29.1)$ & & $10(18.2)$ & \\
\hline \multicolumn{6}{|l|}{ SMOKING } \\
\hline $\mathrm{NO}$ & 152 & $71(46.7)$ & \multirow[b]{2}{*}{0.282} & $41(26.1)$ & \multirow[b]{2}{*}{0.168} \\
\hline YES & 161 & $85(52.8)$ & & $55(34.1)$ & \\
\hline
\end{tabular}

\footnotetext{
* ASCUS:Atypical Squamous Cells of Undetermined Significance

${ }^{\dagger}$ LGSIL:Low Grade Squamous Intraepithelial Lesion

₹ HGSIL:High Grade Squamous Intraepithelial Lesion
} 
Table 4: Multiple logistic regression model: Prognostic factors of HPV infection (any infection and high risk HPV)

\begin{tabular}{|l|l|l|l|l|l|l|}
\hline & \multicolumn{3}{|c|}{ ANY HPV } & \multicolumn{3}{c|}{ High Risk HPV } \\
\hline & OR & 95\% CI & P & OR & 95\% CI & P \\
\hline Age(/year) & 0.97 & $(0.93,1.02)$ & 0.275 & 0.93 & $(0.89,0.98)$ & 0.008 \\
\hline $\begin{array}{l}\text { Number of lifetime sex. } \\
\text { partners }\end{array}$ & \multicolumn{7}{|c|}{} & & & & \\
2 vs. 1 & 1.20 & $(0.46,3.14)$ & 0.710 & 1.50 & $(0.49,4.55)$ & 0.473 \\
3 vs 1 & 2.27 & $(0.86,6.00)$ & 0.098 & 4.04 & $(1.36,12.01)$ & 0.012 \\
>3 vs 1 & 3.19 & $(1.46,7.01)$ & 0.004 & 2.92 & $(1.19,7.15)$ & 0.019 \\
\hline $\begin{array}{l}\text { Pap-test } \\
\text { Ascus/Negative }\end{array}$ & 0.70 & $(0.24,1.99)$ & 0.503 & 0.86 & $(0.22,3.26)$ & 0.819 \\
Negative+other & & & & & & \\
Finding/Negative & 1.40 & $(0.64,3.10)$ & 0.401 & 2.43 & $(0.98,5.98)$ & 0.054 \\
LGSIL,HGSIL/Negative & 2.84 & $(1.24,6.52)$ & 0.014 & 5.62 & $(2.17,14.52)$ & $<0.001$ \\
\hline Warts (Yes/No) & 3.02 & $(1.46 .6 .27)$ & 0.003 & \multicolumn{3}{|c|}{} \\
\hline Deliveries (No/Yes) & 2.56 & $(0.99,6.66)$ & 0.054 & & & \\
\hline
\end{tabular}

\begin{abstract}
ASCUS:Atypical Squamous Cells of Undetermined Significance
LGSIL:Low Grade Squamous Intraepithelial Lesion

HGSIL:High Grade Squamous Intraepithelial Lesion
\end{abstract}


Table 5: Comparative performance between the Linear Array and Amplicor HPV test on 319 samples.

\begin{tabular}{|c|c|c|c|}
\hline LINEAR ARRAY & AMPLICOR (+) & AMPLICOR (-) & TOTAL \\
\hline High risk & $96(82.1 \%)$ & $1(0.5 \%)$ & 97 \\
\hline Low risk & $12(10.3 \%)$ & $49(24.3 \%)$ & 61 \\
\hline Negative & $9(7.6 \%)$ & $152(75.2 \%)$ & 161 \\
\hline TOTAL & 117 & 202 & 319 \\
\hline
\end{tabular}


Figure 1. Prevalence of HPV according to age

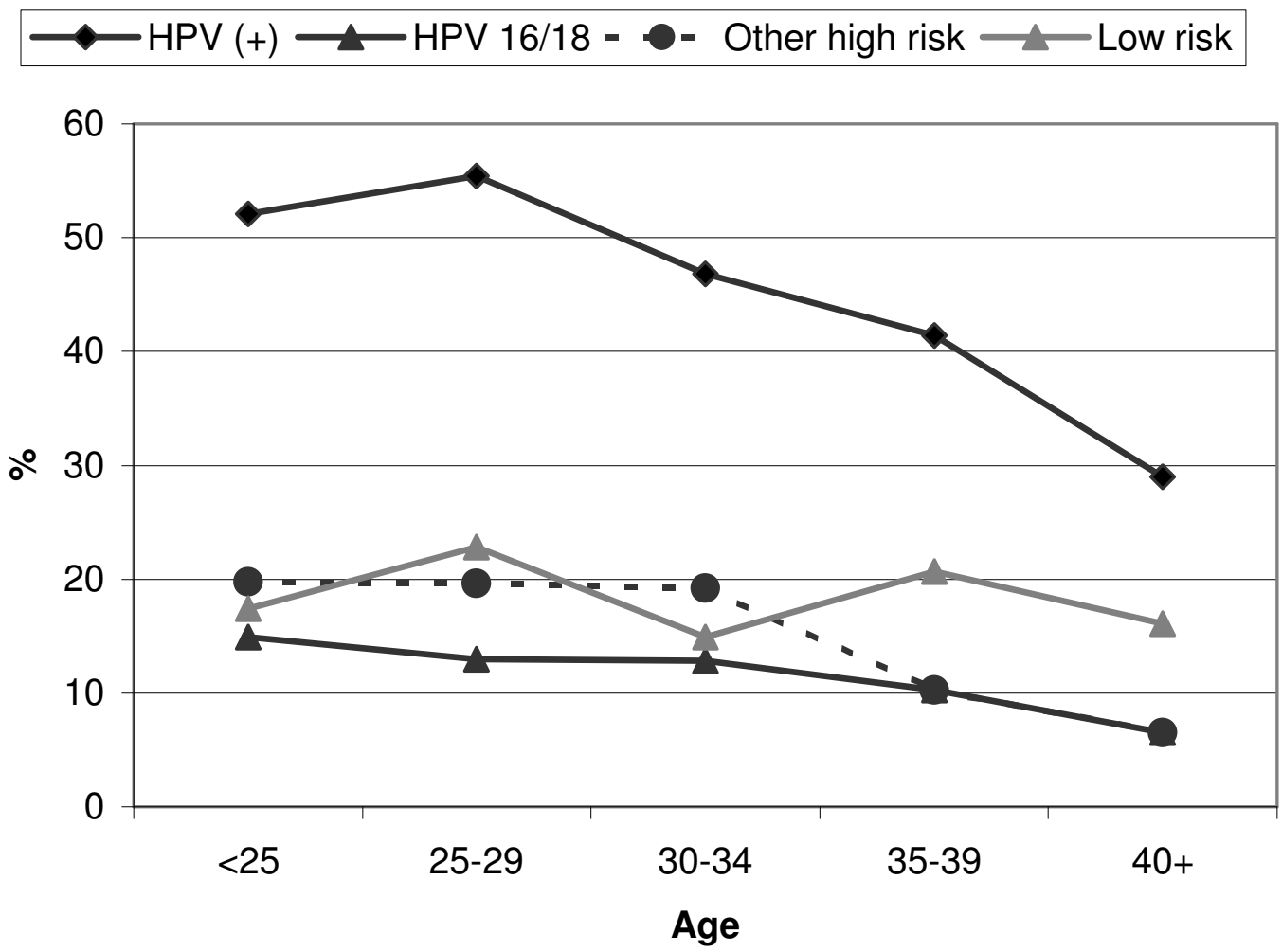

